\title{
TInnGO: Challenging Gender Inequality in Smart Mobility
}

\author{
Andree Woodcock a , Hilda Rømer Christensen ${ }^{b}$, Lena Levinc \\ a Coventry University, UK \\ b University of Copenhagen, Denmark \\ 'VTI, Sweden
}

\begin{tabular}{|c|c|}
\hline ARTICLE INFO & A B S T R A C T \\
\hline $\begin{array}{l}\text { DOI: 10.31075/PIS.66.02.01 } \\
\text { Professional paper } \\
\text { Received: 19.12.2019 } \\
\text { Accepted: } 10.06 .2020 \\
\text { Corresponding author: } \\
\text { A.Woodcock@coventry.ac.uk } \\
\text { Keywords: } \\
\text { TInnGO } \\
\text { Gender } \\
\text { Inclusivity } \\
\text { Smart Mobility }\end{array}$ & $\begin{array}{l}\text { The European transport sector is marked by a strong, persistent unconscious } \\
\text { bias, which produces gendered inequalities that permeate all aspects of the } \\
\text { domain from design, modelling, implementation, education, employment and } \\
\text { usage. The TInnGO project will create a framework and mechanisms for } \\
\text { sustainable change in gender and diversity mobility through the development of } \\
\text { a Pan European TInnGO observatory. This will lead, coordinate, and be fed by } \\
\text { hubs across EU (UK, France, Germany, Greece, Spain, Portugal, Romania, } \\
\text { Baltic states, Denmark/Sweden, Italy) providing international and national } \\
\text { leadership, innovation and critical reviews of smart mobility innovations. The } \\
\text { ambition is to become a template for other observatories to address barriers to } \\
\text { women's mobility through gendered, culturally sensitive smart mobility } \\
\text { innovations. Written during the first year of a 3-year project, the paper provides } \\
\text { an overview of the concept and initial results. }\end{array}$ \\
\hline
\end{tabular}

\section{Introduction}

It has long been recognized that women (and other groups) are significantly marginalized in transport. Without research in this area, smart mobility will continue to exclude these groups (e.g. the elderly, those from lower income backgrounds, with mobility, cognitive, sensory and communication difficulties). The Transgen report from 2007 pointed to marked gender differences in the daily use and practices of a shared transport system, in labour market participation and opportunities, in politics and research committees as well as in cultural images and stereotypes. Examples of gender differences have continued along the same lines e.g.

- Commuting journeys from point $A$ to $B$ are privileged by transport systems, over those related to more complex home, social, and health care journeys.

- The complex, multi-legged journeys by women and those in lower socio-economic groups are not modelled; therefore future systems will perpetuate the same inequalities.

\footnotetext{
1 This paper was presented at the 7th International Conference „Towards a Humane City", 6-7th Decembar 2019. in Novi Sad, Republic of Serbia.
}

- In Europe over $70 \%$ of the transport workforce are male. If unchecked, this may limit the opportunities for women's and other marginalized groups' employment and education in this field, and the inclusivity of Smart Transport innovations.

- Since 1945 , only $7 \%$ of the transport ministers in TInnGO countries have been female. This is further reflected in research committees that have significant gender gaps and imbalances [1]. These pose democratic problems and barriers to developing equitable innovative future transport systems.

- Gendered and non-inclusive discourses are being used to promote smart mobility in marketing, advertising and in technology led conferences

- Informal workplace interactions reproduce stereotypical associations of the transport sector as a place for 'masculine' work

- Women face higher risks and burdens than men in transport [3]. Additionally, some may be subjected to entrenched social and cultural norms that limit their mobility.

- The lack of awareness of gendered imbalances means that gender inequality persists and that there is practically no progress in gender smart mobility options 
The great hopes of smart mobility, not least autonomous cars, as a solution to former transport inequalities have already been undermined by emerging imbalances; e.g., the belief in technological solutions and the idea of the businessman as the main target for smart mobility solutions have been revealed in several studies in and across Europe and the Western world. Besides emerging gender-gaps have been recognized in both the UK and in the Nordic region this new discipline [2].

The TInnGO project builds on and extends existing European gender and transport projects, notably:

- the Transgen project [1] which outlined gender gaps, the usefulness of gender mainstreaming (GM) in transport systems, transport labour market, and the gendered character of transport -related media;

- the EIGE report [4] that substantiated transport and sustainability as a vital part of the European responses to the Beijing Platform of Action and equality gaps;

- the DGMove report [5] which documented the different travel patterns and concerns of male and female transport users, the limited attention placed in developing gender-specific policies, programmes, and mandates, the evolution of intersectional issues such as employment trends, reduction in traditional gender divisions around household roles and responsibilities and 'mobility of care' as a concept to explain trip chaining

Unfortunately, despite the vast body of knowledge and numerous policy recommendations [1, 6], groundbreaking changes in European transport priorities or policies [7] have not been found.

The TInnGO project seeks to address this by building on previous studies:

- focusing on intersectional perspectives, for example, related to socio cultural categories such as class, ethnicity, and age particularly in relation to smart and sustainable mobility,

- by creating gender and diversity awareness and action plans which can be translated into different cultural contexts to develop gender and diversity sensitive smart mobility as a fundamental component of a smart city.

\section{Approach}

TInnGO aims to promote a sustainable game change in the European transport by creating a new observatory, conceived as a one-stop shop for analysis and solutions on the inequalities women face in the transport sector. It takes a three-pronged approach looking at gender and diversity issues in transport usage, employment and education. This will include:
1. The creation of a Pan European observatory for gender smart transport innovation in the Smart Mobility sector. This will provide a nexus for data collection, analysis and dissemination of gender mainstreaming tools and open innovation. The observatory will collect existing resources to become the reference portal for those wishing to address gender and diversity sensitive smart mobility. It will freely provide best practices, case studies, guidelines, tools, methodologies, training, policy documents and videos. Specific sections will allow users to participate in open innovation and share content, insights and data for collaboration

2. The central observatory will be fed by 10 national hubs and laboratories (Baltic States, Italy, Greece, Norway/Sweden, UK Midlands, France, Romania, Germany, Spain and Portugal) each specialising in a local issue relating to gender and inclusivity (e.g. safety, needs of women from minority groups, entrepreneurship). The hubs will:

a. use project outputs (such as gender action plans and gender mainstreaming tools) to address local issues in Transport Business Ecosystem (TBE) (such as gendered workplaces, inclusive consultation, entrepreneurship and education).

b. provide national data relating to the (TBE) for example through standardised surveys on women's mobility

c. act as beacon for women's engagement in the smart mobility sector

d. provide 'living labs' drawing on citizen science and participatory design to create gender and diversity-sensitive smart mobility solutions,

3. Development of an Open Data Repository - a one stop shop for sharing transport related gender datasets with standardised templates, tools and GDPR compliant data management processes.

4. Application of digital analysis and agent-based modelling as new tools in transport analysis and visioning. Where possible, TInnGO will work with existing knowledge, but in new ways that connect to the overall aim of an innovative and smart transport system as well as the barriers for diverse groups of women in transport as labour market. TInnGO will apply Agent-based modelling and digital Data mining to existing data to provide a body of visual and disaggregated data that sheds light on the diversity of transport needs in ten specifically defined local/national hubs. The ambition is to provide a comprehensive understanding of actual problems and prospects and of transformative solutions 
Proposed areas of impact will be in the areas of:

- education and R\&I( gender and role equality in $\operatorname{STE}(A) M$, engineering and design);

- employment (gender bias in opportunities and workplace);

- mobility (increased awareness and use of 'hidden' journeys);

- datasets (standardize, create and merge datasets enabling better data analytics on women's mobility);

- entrepreneurship (document and transfer best practice);

- policy at local, national \& international level (more accurate mobility information, integrated planning and diversity in policy making bodies);

- practice (increase equality in consultation, decision making and employment practices);

- new knowledge (about intersectionality and gender transport poverty);

- creation of inclusive smart mobility solutions putting people first;

- smart mobility discourses (critical analysis and development of new scripts).

\section{Conceptual Framework}

TInnGO has adopted a Roadmap [14] on conceptual and methodological framework. The Roadmap provides an elaborated overview on gender in the emerging field of smart transport. Further, the Roadmap describes central topics in the field of gender, diversity and transport.

The Roadmap will help to identify gendered gaps in transport in the study locations in Europe and to approach and analyse these issues. Based on this knowledge, the Roadmap lays out the TInnGO vision of a Gender Smart Mobility system.

The TInnGO concepts toolbox consists of:

Smart Transport refers to forms of transportation that aim to reduce the 21st Century's big transport challenges, such as traffic congestion, environmental pollution, fatalities, and time-waste. Smart Transport can take different forms, including public transportation, walking, and biking.

Gender refers to the social construction of roles, responsibilities, and obligations associated with being a woman or a man. Gender emphasizes the social meaning-making of gendered identities, and it opens up for more than two genders, such as transgender, or non-binary gender.
Diversity points to the inclusion of more social categories, such as age, ethnicity, class, sexuality, disabilities, etc. Working with diversity in research, planning and policy-making means to be aware of how the category of women, for example, does not represent a single group, but contains large differences due to variables of age, class, etc.

Gender Smart Mobility refers to forms of transport that take gender and diversity into consideration. The focus on Gender Smart Mobility departs from the findings of the report TRANSGEN [1] that provided a thorough mapping of research that linked the perspectives of gender to the field of transport, research and policies. Gender Smart Mobility connects to current actions of transport research, policy-making and planning [e.g. 15], which react on and meet the needs and aspirations of different genders as well as other social groups.

Gendered scripts and inclusive language Gendered scripts address the gendered dimensions of mobile technologies be it cars, bikes or walking devises. An analysis of gendered scripts looks into the assembly of various materialities, the practices of transportation, and the connection of certain identities to specific modes of transport. Inclusive language refers to the use of language, which embraces different kinds of people instead of expelling them. Using Inclusive language means to constantly consider the gendered stereotypes in the transport sector and reflect upon how to include all groups of people in a respective way.

\section{Methodology}

Our work will be underpinned by key concepts and tools related to intersectionality, gender transport poverty, gendered discourses, scripts and agentbased modelling.

TInnGO will use and advance gender mainstreaming (GM) which has proven useful in the promotion of gender equal transport with its duel focus on just and accessible transport and in achieving gender equality in the transport labour market. GM consists of tools to identify imbalances and inequalities in processes where gender has been invisible or regarded as unimportant [8]. It has been suggested as a tool for mobilization and participation and for addressing gender and diversity in new ways $[9,10]$ TInnGO will advance GM into diversity mainstreaming exploring influences on travel and transportation needs [9-12].

Given the project's scope, a mixed method, pragmatic approach has been developed (Table 1). Many of these, such as the use of intersectional analysis, codesign and citizen science are innovative in the field of gender and transport. 
Table 1. Overview of methods to be used in TInnGO

\begin{tabular}{|c|c|}
\hline Method & Description \\
\hline $\begin{array}{l}\text { Gender and diversity } \\
\text { Smart Mainstreaming }\end{array}$ & $\begin{array}{l}\text { TInnGO will further develop and employ } \\
\text { models of gender mainstreaming in } \\
\text { transport }\end{array}$ \\
\hline Mixed methods & $\begin{array}{l}\text { Quantitative and qualitative methods will } \\
\text { provide thick explanations and new } \\
\text { hypotheses for gendering and diversifying } \\
\text { key notions and gendered/genderless } \\
\text { stereotypes such as user, passenger, } \\
\text { safety, smart mobility }\end{array}$ \\
\hline $\begin{array}{l}\text { Qualitative research } \\
\text { methods (feminist social } \\
\text { psychology methods + } \\
\text { Personal Construct } \\
\text { Psychology+citizen } \\
\text { social science tools and } \\
\text { methods }\end{array}$ & $\begin{array}{l}\text { Feminist research acknowledges the } \\
\text { centrality of female/gendered knowledge } \\
\text { and experience and the social construction } \\
\text { of meaning, with emphasis on the role of } \\
\text { language as the primary vehicle to } \\
\text { enhance criticality of thinking, broaden } \\
\text { research scope providing an extra } \\
\text { dimension by adding to understanding of } \\
\text { women's daily lives. }\end{array}$ \\
\hline Quantitative methods & $\begin{array}{l}\text { Development of an interrogatable and } \\
\text { standardised open access and open data } \\
\text { repository combining historic and real-time } \\
\text { data sets for use with intersectional } \\
\text { analysis to uncover new and significant } \\
\text { mobility patterns. These will be modelled } \\
\text { to evaluate and inform existing policies, } \\
\text { operational issues, transport infrastructure } \\
\text { and innovation. }\end{array}$ \\
\hline $\begin{array}{l}\text { Big data analytics and } \\
\text { Agent Based Modelling } \\
\text { (ABM) }\end{array}$ & $\begin{array}{l}\text { ABM entails the sampling of the } \\
\text { quantitative data collections into a larger } \\
\text { data scenario perspective. This will be } \\
\text { used for enhancing data and strategies; } \\
\text { geographical comparisons; advancing GM; } \\
\text { validation of qualitative data; } \\
\text { consciousness raising and new policy } \\
\text { recommendations }\end{array}$ \\
\hline $\begin{array}{l}\text { Digitalized and visual } \\
\text { methods }\end{array}$ & $\begin{array}{l}\text { Media and visual analysis will be } \\
\text { combined with textual and visual } \\
\text { methodologies to understand how future } \\
\text { scenarios of smart mobilities are } \\
\text { embedded in existing and emerging } \\
\text { gendered discourses. Themed discourse } \\
\text { analysis will provide a knowledge based } \\
\text { comparative analysis of various gender } \\
\text { diversity and transport discourses } \\
\text { throughout Europe, using national media } \\
\text { archives as data material and together } \\
\text { with a visual analysis of marketing material } \\
\text { a knowledge-based analysis of smart } \\
\text { mobilities. }\end{array}$ \\
\hline Case studies & $\begin{array}{l}\text { Giving a multi-perspective analysis to } \\
\text { develop theory, evaluation and } \\
\text { interventions. }\end{array}$ \\
\hline $\begin{array}{l}\text { HUBs as living labs/mini } \\
\text { publics }\end{array}$ & $\begin{array}{l}\text { The TInnGO Hubs (each having a specific } \\
\text { area of interest based on local concerns, } \\
\text { e.g. safety, bicycling, design) will function } \\
\text { as living labs, according to principles of } \\
\text { deliberate and participatory democracy, } \\
\text { user-centred design and open-innovation } \\
\text { to inform practice, policy and act as a } \\
\text { collection point for issues relating to } \\
\text { women's mobility. }\end{array}$ \\
\hline
\end{tabular}

\section{What has happened to Gender Mainstreaming (GM) in Transport?}

Gender mainstreaming is a strategy to incorporate a gender perspective into all decisions and in the planning, implementation, monitoring and development of the activities and operations.

Researchers [13] performed a desktop review on current methods and tools on gender and diversity mainstreaming tools in the transport sector in TInnGO' s participating countries, i.e. in: Denmark, France, Germany, Greece, Italy, Lithuania, Portugal, Romania, Spain, Sweden, and United Kingdom.

Although variations were found between countries both regarding gender and diversity mainstreaming and in the availability of published material, none of the eleven countries have sufficiently developed and applied methods for gender and diversity mainstreaming in the transport sector and they seem to lack overall strategies on national level. More considered approaches were found in some local Authorities and funded applied research projects. Examples of best practice (as shown in Table 2) were identified from ongoing work in Germany, UK, Spain (Valencia), Italy, Denmark and Sweden which could form the basis of a toolbox and disseminated through the observatory.

Table 2. Examples of best practice in GM in partner cities

\begin{tabular}{|l|l|}
\hline Country & Practice \\
\hline Germany & $\begin{array}{l}\text { Handbuch Gender Mainstreaming in der Stadtplanung } \\
\text { und Stadtentwicklung" - awareness-raising handbook for } \\
\text { gender-sensitive issues in interdisciplinary planning. }\end{array}$ \\
\hline Sweden & $\begin{array}{l}\text { 1) Manual on gender impact assessment for transport } \\
\text { planning (Halling, Faith-Ell \& Levin 2016) provided } \\
\text { examples, analysis questions and indicators for each } \\
\text { national gender equality objective. 2) "Gender } \\
\text { mainstreaming with intersectional perspective" (Almén }\end{array}$ \\
2016) providing a basic introduction to intersectionality \\
\hline Denmark & $\begin{array}{l}\text { Handbook on gender equality and transport: } \\
\text { "Bæredygtig \& Ligestillet Transport" (Breengaard 2008) } \\
\text { presents challenges in relation to knowledge about } \\
\text { women's and men's transport needs }\end{array}$ \\
\hline UK & $\begin{array}{l}\text { Regional/local examples of publications, initiatives and } \\
\text { guidance e.g. the Transport for London's (TfL) "Manual } \\
\text { for the streets" (2007) and "Streetscape Guidance" } \\
\text { (2019) }\end{array}$ \\
\hline Spain & $\begin{array}{l}\text { 1) Equal Opportunities Strategic Plan sets out priority } \\
\text { measures and objectives for removing gender-based } \\
\text { discrimination to attain equal opportunities. 2) Madrid } \\
\text { Social Policy and Family Regional Ministry -Women's } \\
\text { General Directorate have developed a strategy for } \\
\text { gender equality which includes measures related to } \\
\text { transport.3) In Valencia GM is being incorporated into } \\
\text { public policy and support manuals/handbooks exist in } \\
\text { relation to this. The SUMP has inclusivity objectives }\end{array}$ \\
\hline Italy & $\begin{array}{l}\text { Regional initiatives directed at women in public transport } \\
\text { and car parking and car-sharing; e.g. "pink passes", } \\
\text { reduced off-peak travel rates in public transport; "pink } \\
\text { parking", parking spaces or free parking for pregnant } \\
\text { women or women with babies in certain places. }\end{array}$ \\
\hline
\end{tabular}




\section{Summary and Conclusions}

TInnGO is taking a multifaceted, ground -up and bottom-down approach, providing both tools and methods to encourage the use of GM in transport and smart mobility. The hubs will act as touch points across Europe disseminating good practice and encouraging the development of diversity sensitive smart mobility solutions to local problems. We hope, in this way that we can increase the inclusivity of smart transport for all.

\section{Acknowledgements}

The TInnGo project is funded by $\mathrm{H} 2020$ in response to the EU call 'MG4-3-3018: Demographic change and participation of women in transport', project number 824349

\section{TInnGO: Оспоравање неједнакости полова у паметној мобилности}

\section{Andree Woodcock}

Coventry University, UK

Hilda Rømer Christensen,

University of Copenhagen, Denmark

\section{Lena Levinc}

VTI, Sweden

Резиме: Европски транспортни сектор обележен је снажном, постојаном несвесном предрасудом, која ствара родне неједнакости које прожимају све аспекте домена од дизајна, моделирања, примене, образовања, запошљавања и коришћења.

Пројекат TInnGO створиће оквир и механизме за одрживу промену мобилности полова и разноликости кроз развој Паневропске опсерваторије TInnGO. Ово ће водити, координирати и снабдевати средишта широм ЕУ (Велика Британија, Француска, Немачка, Грчка, Шпанија, Португал, Румунија, балтичке државе, Данска / Шведска, Италија) пружајући међународно и национално лидерство, иновације и критичке прегледе паметне мобилности иновације. Амбиција је постати образац за друге опсерваторије како би се решиле баријере за мобилност жена путем родних, културно осетљивих иновација паметне мобилности. Написан током прве године трогодишњег пројекта, рад даје преглед концепта и почетних резултата.

Кључне речи: TInnGO, пол, инклузивност, паметна мобилност

\section{References}

[1] Transgen Project Gender Mainstreaming European Transport Research and Policies. (2007). Building the Knowledge Base and Mapping Good Practices. https://koensforskning.soc.ku.dk/projekter/transgen/.

[2] Transport Systems Catapult. (2016). Intelligent Mobility Skills Strategy. https://s3-eu-west- content/uploads/2016/10/31095944/3383 IM-

Skills_Business-Case_Brochure.pdf.

[3] A. Woodcock et al. (2019). Developing a transport innovation gender observatory to address gender inequalities in transport in Europe, WIIT Conference, Washington.

[4] European Institute of Gender Equality (EIGS). (2012). Gender Equality and Climate Change: Review of the Implementation in the $E U$ of area $K$ of the Beijing Platform for Action: Women and the Environment. 2012. https://eige.europa.eu/topics/environment-and-climatechange.

[5] European Commission (DG MOVE). (2014). She Moves Women's Issues in Transportation. https://civitas.eu/content/she-moves.

[6] Schiebinger, L., Klinge, I., Paik, H. Y., Sánchez de Madariaga, I., Schraudner, M., \& Stefanick, M. (Eds.) (20112018). Gendered Innovations in Science, Health \& Medicine, Engineering, and Environment. genderedinnovations.stanford.edu.

[7] European Union. (2018). Year of Multimodality. https://ec.europa.eu/transport/themes/logistics-andmultimodal-transport/2018-year-multimodality_en. Accessed 15 May 2019.

[8] Christensen, H.R. (2011). Mainstreaming Gender, Diversity and Citizenship: Concepts and Methodologies. Femcit Report. Working paper, No 3.https://koensforskning.soc.ku.dk/projekter/femcit/Mainstrea ming_Gender_Diversity_and_Citizenship_Concepts_and_M ethodologies.pdf/.

[9] Booth, C., \& Bennett, C. (2002). Gender mainstreaming in the European Union: towards a new conception and practice of equal opportunities?. European Journal of Women's Studies, 9(4), 430-446.

[10] Rees, T. (2005). Reflections on the uneven development of gender mainstreaming in Europe. International Feminist Journal of Politics, 7(4), 555-574.

[11] Christensen, H.R, Poulsen, H., Oldrup, H., Malthesen, T., Breengaard, M.H.,, \& Holmen, M. (2007). Gender Mainstreaming European Transport Research and Polices. Building the Knowledge Base and Mapping Good practices.https://koensforskning.soc.ku.dk/projekter/transgen/ eu-rapport-transgen.pdf/.

[12] Clark, F., \& Illman, D. L. (2001). Dimensions of civic science: Introductory essay. Science communication, 23(1), 5-27.

[13] Ihlström, J., Levin, L., \& Henriksson, M. (2019). Review of methods and tools for gender and diversity mainstreaming, D6.1 TinnGO, September.

[14] Christensen, H.R., \& Breengaard, H.M., (2019). Conceptual coordination: Translating theory into practice, D4.1 TInnGO, June.

[15] Uteng T.P, Christensen, H.R., \& Levin, L. (Eds.). (2020) Gendering Smart Mobilities. London and New York: Routledge.

[16] Christensen, H.R, \& Breengaard M.H. (2019). Gender and diversity In digital analysis. Report from a workshop. D.4.4. TINNGO, December. 